Гончар Л. О., к.е.н., старший викладач

Аухімік О. В., магістрант

Київський національний університет культури та мистецтв

м. Київ, Украӥна

DOI: https://doi.org/10.30525/978-9934-26-028-5-21

\title{
МОДЕРНІЗАЦІЯ БІЗНЕС-ПРОЦЕСІВ ПІДПРИЕМСТВ ГОТЕЛЬНО-РЕСТОРАННОГО БІЗНЕСУ НА ОСНОВІ КОНТРОЛІНГУ
}

В умовах посилення економічної кризи, нестабільності зовнішнього середовища, цифровізації економічних процесів, збільшення кількості інформації та інших факторів у готельноресторанному бізнесі виникає необхідність застосування новітніх підходів щодо підвищення ефективності управління підприємством. На території України всі підприємства сфери гостинності відчули на собі наслідки економічної кризи, саме тому проблема оптимізації та модернізації бізнес-процесів на основі контролінгу в діяльності підприємства стала ще актуальнішою.

Підприємство готельно-ресторанного бізнесу - це складна система, діяльність якої можна охарактеризувати набором бізнеспроцесів різних рівнів, зокрема: управлінського, операційного та функціонального. Проте у зв'язку із кризовим становищем економіки, що викликана пандемією COVID-19, функціонування бізнес-процесів на підприємствах готельно-ресторанного бізнесу потребує значних змін та уточнень.

Для модернізації бізнес-процесів підприємств сфери гостинності створюють систему управління цими процесами. Тому для забезпечення конкурентоспроможності та ефективності діяльності підприємств слушним є подальше формування та розвиток системи контролінгу на підприємстві.

Контролінг є одним із сучасних напрямів розвитку теорії та практики обліку, контролю та аналізу господарської діяльності підприємств. Багато науковців вивчає цей напрям та активно займається його розповсюдженням та впровадженням. На думку 
фахівців, сучасний бізнес дуже залежить від контролінгу та не зможе ефективно функціонувати без його участі.

Для забезпечення ефективного протікання бізнес-процесів на підприємстві сфери гостинності доцільним $є$ проектування структурної моделі системи контролінгу у закладах готельноресторанного бізнесу, повинна характеризуватись комплексністю, охоплювати головні напрямки функціонування підприємства та загалом мати цілісну і єдину структуру (рис. 1).

Структурна модель системи контролінгу в закладах готельноресторанного бізнесу базується на трьох підсистемах підсистема 1 (ресторан), підсистема 2 (готель), підсистема 3, що грунтуються на відповідних мікросистемах. Підсистема 1 та підсистема 2 представленої моделі поділяються на служби, які входять до складу готельно-ресторанного підприємства, а підсистема 3 включає в себе спільні адміністративноуправлінські служби, що дає зрозуміти нерозривність моделі функціонування системи контролінгу в закладах готельноресторанного бізнесу.

Ключовим завданням системи контролінгу на підприємствах готельно-ресторанного бізнесу в розрізі модернізації бізнеспроцесів є збір та аналіз внутрішньої та зовнішньої інформації, 3 метою прийняття оптимальних рішень і необхідних дій для забезпечення життєдіяльності підприємства в короткостроковому та довгостроковому періодах, шляхом постійного моніторингу ефективності діяльності підприємства в умовах змін зовнішнього середовища.

Відповідно до завдання виділяють три ключові функції системи контролінгу готельно-ресторанному бізнесі [2]:

- сервісна;

- функція прийняття рішень;

- внутрішній контроль на підприємстві.

Реалізація сервісної функції на підприємствах сфери гостинності зумовлюється необхідністю забезпечення актуальної інформації для управління за допомогою системи планування, обліку та контролю. 


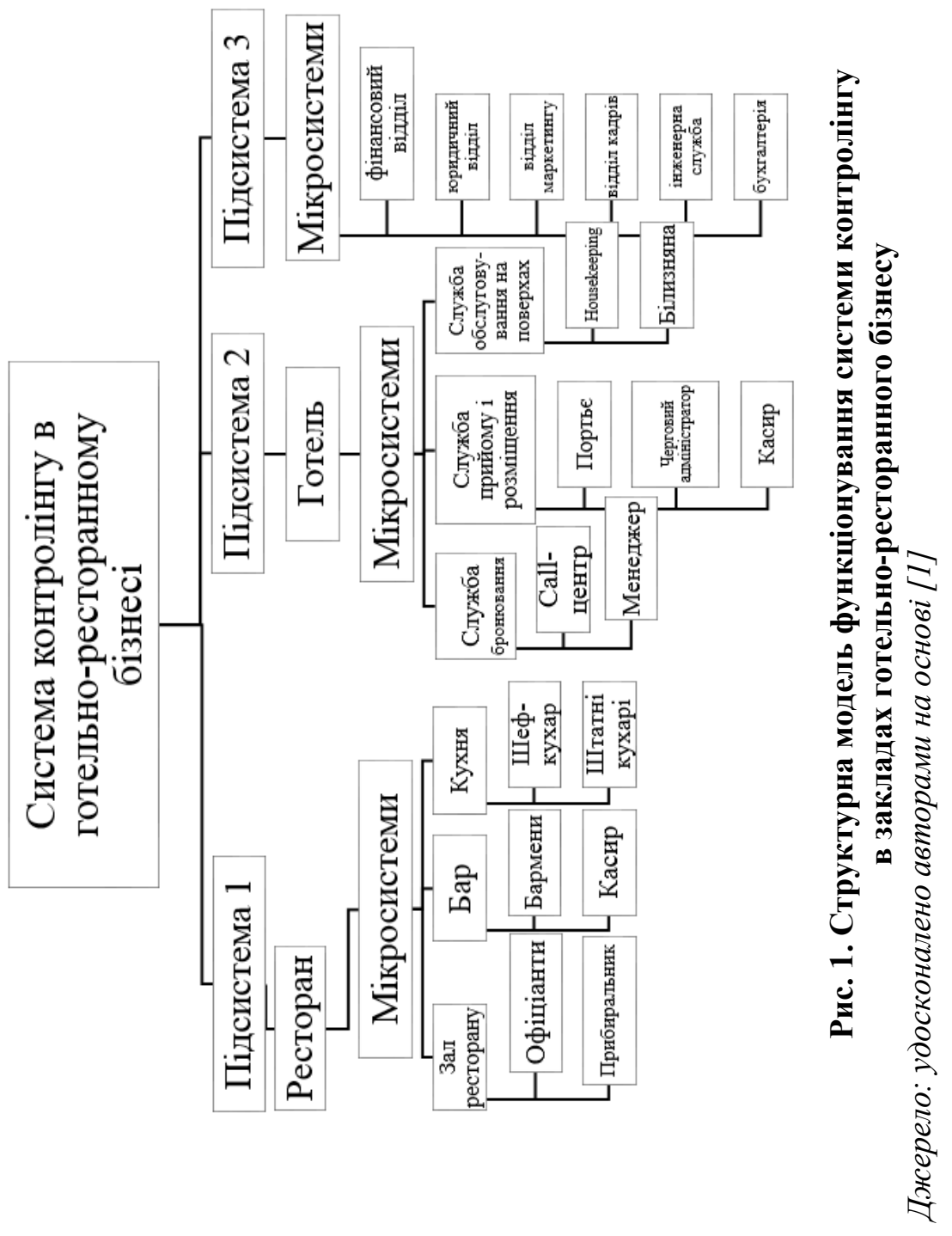


Функцію прийняття рішень ще називають функцією управління, оскільки на основі даних аналізу відхилень та загальних результатів діяльності підприємства приймаються оперативні та стратегічні управлінські рішення.

Функція внутрішнього контролю регулює економічну роботу підприємства та його структурних підрозділів.

Впровадження системи контролінгу в діяльність підприємств готельно-ресторанного бізнесу задля модернізації ключових бізнес-процесів відбувається у розрізі двох фаз, кожна 3 яких поділяється ще на два етапи.

Перша фаза - підготовча і однойменна першому іiі етапу. Основними процедурами, що повинні виконуватись на 1-му етапі $\epsilon$ - визначення цілей підприємства, аналіз та оцінка зовнішніх та внутрішніх факторів та визначення завдань контролінгу. На 2-му етапі відбуваються організаційні процеси, тобто визначення місця контролінгу на підприємстві, визначення відділу контролінгу, закладання бюджету на впровадження системи контролінгу, розробка документації, визначення штату працівників.

Друга фаза - фаза впровадження - поділяється на етап забезпечення функціонування системи контролінгу, що включає технічне та інформаційне забезпечення функціонування системи контролінгу, та етап формування інструментарію контролінгу, що, у свою чергу, охоплює визначення показників функціонування системи контролінгу, створення документації, розроблення комплексної системи показників ефективності та форм контролінгової звітності [3].

Процес запровадження контролінгу для підвищення результативності протікання бізнес-процесів на підприємствах готельноресторанного бізнесу супроводжується опором та ускладненням. Контроль за кожним етапом виконання завдань викликає певний дискомфорт та незадоволення 3 боку системних працівників. Досягнути необхідного безперебійного та постійного (системного) функціонування закладів сфери гостинності можна шляхом налагодження діяльності усіх бізнес-процесів на підприємстві 
та здійсненням регулярного контролю за їх виконанням [4]. Для цього здійснюють діагностику ефективності бізнес-процесів на підприємствах готельно-ресторанного бізнесу у розрізі їх модернізації на основі контролінгу за алгоритмом, що відображений на рис. 2.

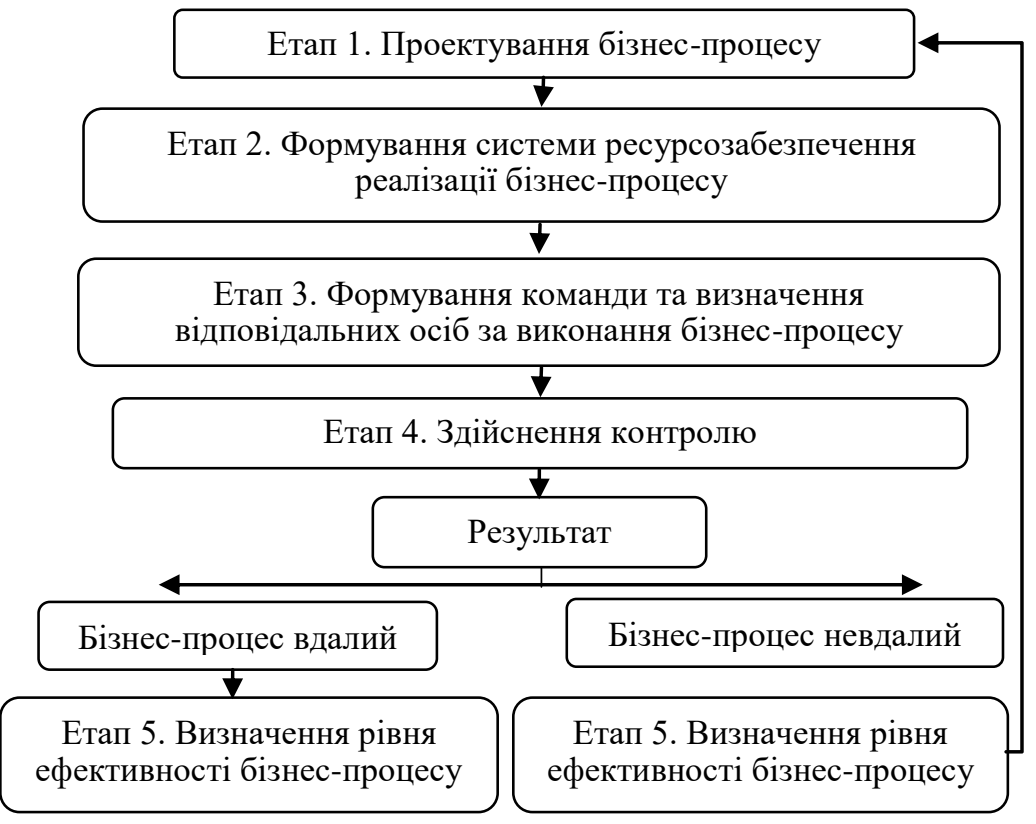

\section{Рис. 2. Алгоритм діагностики ефективності бізнес-процесів на підприсмствах готельно-ресторанного бізнесу у розрізі їх модернізації на основі контролінгу}

Джерело: систематизовано та удосконалено авторами на основі [4]

На підприємстві діагностика ефективності контролінгу бізнеспроцесів являє собою процес ідентифікації, аналізу та оцінювання рівня ефективності системи контролінгу, яка спрямована на контроль його бізнес-процесів і ліквідацію проблемних моментів та/чи слабких сегментів організації. Основною метою діагностики $€$ визначення якісного рівня розвитку підприємства 3 
орієнтацією на підвищення його конкурентоспроможності й інвестиційної привабливості.

Отже, модернізація бізнес-процесів шляхом запровадження системи контролінгу в закладах готельно-ресторанного бізнесу $є$ досить релевантним та адекватним рішенням в умовах невизначеності, спричинених, зокрема, пандемією COVID-19. За допомогою комплексної системи контролінгу підприємства готельно-ресторанного бізнесу забезпечують відслідковування за процесом виконання бізнес-процесів, що, у свою чергу, забезпечують ефективне функціонування самого підприємства.

Своєчасне та регулярне контролювання бізнес-процесів допомагає усунути небажані відхилення, що дозволяє підприємствам готельно-ресторанного бізнесу зберігати фінансову стійкість та підвищити конкурентоспроможність як окремого підприємства, так і сфери гостинності в цілому.

\section{Література:}

1. Гончар Л.О., Аухімік О.В. Система контролінгу в готельноресторанному бізнесі: теоретико-прикладний аспект. Fundamental and applied research in the modern world. 2020. Boston. C. 433-439.

2. Пакуліна А.А., Шебалкова Е.І. Контролінг та його функції на підприємстві. Всеукраӥнська науково-практична інтернет-конференція «Управління та адміністрування: конкурентні виклики сучасності» - 2020. Харків. C. 201-203 URL: https://kstuca.kharkov.ua/wpcontent/uploads/2020/10/ Zbirnuk_Kafedra_menedgmenty_15.2020.pdf\#page=202.

3. Циганова О.С. Етапізація процесу впровадження системи контролінгу на промислових підприємствах. Вісник Запорізького начіонального університету. 2017. № 2(34). С. 27-34.

4. Скриньковський Р. М. Павловські Г., Воробйов В.В. Діагностика ефектив-ності контролінгу бізнес-процесів підприємства. Бізнес Інформ. 2016. № 8. C. 154-159. URL: https://cyberleninka.ru/article/n/diagnostika-efektivnostikontrolingu-biznes-protsesiv-pidpriemstva/viewer.

5. Шубович I.I. Удосконалення менеджменту підприємства шляхом створення системи бізнес-процесів. Менеджмент ХХІ століття: сучасні моделі, стратегіï, технологіï. Вінниця. 2018. С. 724-729. 